\title{
JURAL
}

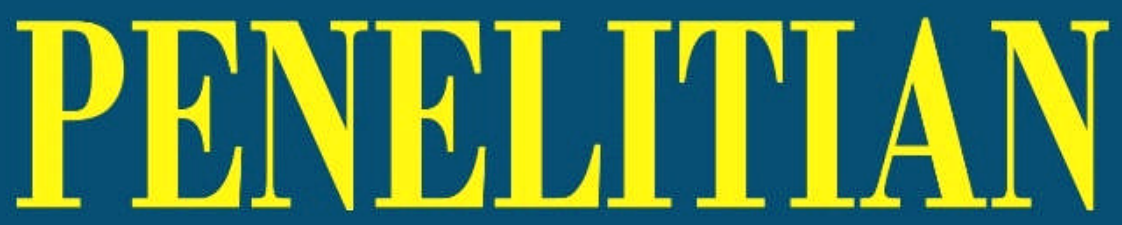

PERIKANAN

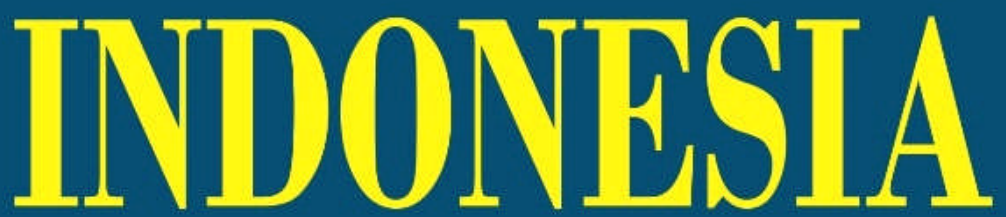




\title{
JURNAL PENELITIAN PERIKANAN INDONESIA
}

bulan MARET, JUNI, SEPTEMBER, dan DESEMBER.

\section{Ketua Penyunting:}

Prof. Dr. Ir. Wudianto, M.Sc. (Teknologi Penangkapan Ikan-Pusat Riset Perikanan)

\section{Dewan Penyunting:}

Prof. Dr. Ir. Ngurah Nyoman Wiadnyana, DEA. (Ekologi Perairan-Pusat Riset Perikanan) Prof. Dr. Ir. Husnah, M. Phil. (Taksikologi-Pusat Riset Perikanan)

Prof. Dr. Ali Suman (Biologi Perikanan Udang-Balai Riset Perikanan Laut)

Prof. Dr. Eko Sriwiyono, S.Pi, M.Si. (Teknologi Kapasitas Penangkapan Ikan-Institut Pertanian Bogor) Dr. Ir. Dewa Gede Raka Wiadnya, M.Sc. (Lingkungan dan Sumber Daya Ikan-Universitas Brawijaya)

\section{Editing Bahasa:}

Andhika Prima Prasetyo, S.Pi., M.Sc. (Sumber Daya dan Lingkungan-Pusat Riset Perikanan)

\section{Penyunting Pelaksana: \\ Dra. Endang Sriyati \\ Darwanto, S.Sos. \\ Amalia Setiasari, A.Md.}

Administrasi:

Arief Gunawan, S. Kom

\author{
Alamat Redaksi/Penerbit: \\ Pusat Riset Perikanan \\ Jl. Pasir Putih II Ancol Timur Jakarta Utara 14430 \\ Telp. (021) 64700928, Fax. (021) 64700929 \\ Website : http://ejournal-balitbang.kkp.go.id/index.php/jppi \\ e-mail:jppi.puslitbangkan@gmail.com
}

Jurnal Penelitian Perikanan Indonesia diterbitkan oleh Pusat Riset Perikanan - Badan Riset dan Sumber Daya Manusia Kelautan dan Perikanan-Kementerian Kelautan dan Perikanan. 


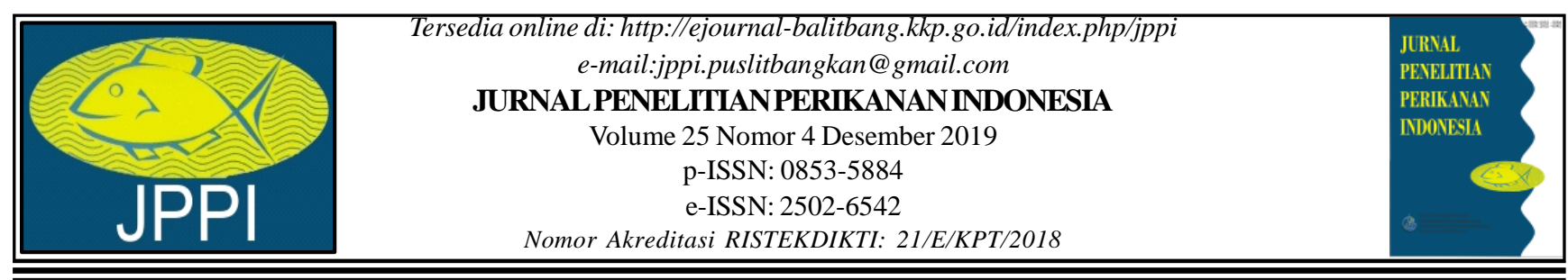

\section{LEMBAR INDEKSASI}

\section{FOKUS DAN RUANG LINGKUP JURNAL PENELITIAN PERIKANAN INDONESIA}

Jurnal Penelitian Perikanan Indonesia (http://ejournal-balitbang.kkp.go.id/index.php/jppi) memiliki p-ISSN 08535884; e-ISSN 2502-6542 dengan Nomor Akreditasi Kementerian RISTEKDIKTI: 21/EKPT/2018. Terakreditasi Peringkat 2 (Dua) berlaku selama 5 (Lima) Tahun, (Periode Volume 22 Nomor 1 Tahun 2016-Volume 26 Nomor 4 Tahun 2020). Terbit pertama kali tahun 1994. Tahun 2006, frekuensi penerbitan tiga kali dalam setahun pada bulan April, Agustus dan Desember. Tahun 2008, frekuensi penerbitan menjadi empat kali yaitu pada bulan Maret, Juni, September dan Desember.

Jurnal Penelitian Perikanan Indonesia adalah wadah informasi perikanan, baik laut maupun perairan umum daratan. Jurnal ini menyajikan hasil penelitian sumber daya, penangkapan, oseanografi, lingkungan, rehabilitasi lingkungan dan pengkayaan stok ikan.

Naskah yang diterbitkan di Jurnal Penelitian Perikanan Indonesia telah melalui pemeriksaan pedoman penulisan oleh Administrasi Jurnal, naskah yang sudah mengikuti pedoman penulisan direview oleh 2 (dua) orang Dewan Penyunting dan 1 (satu) orang Bebestari (Peer-Reviewer) berdasarkan penunjukan dari Ketua Dewan Penyunting. Keputusan diterima atau tidaknya suatu naskah menjadi hak dari Ketua Dewan Penyunting berdasarkan atas rekomendasi dari Dewan Penyunting dan Bebestari.

\section{INFORMASI INDEKSASI JURNAL}

Jurnal Penelitian Perikanan Indonesia (http://ejournal-balitbang.kkp.go.id/index.php/jppi) memiliki p-ISSN 08535884; e-ISSN 2502-6542 yang sudah terindeks di beberapa pengindeks bereputasi, antara lain: Cross Ref, Indonesian Scientific Journal Database (ISJD), SCILIT, Sherpa/Romeo, Google Scholar, Directory Open Access Journals (DOAJ), Bielefeld Academic Search Engine (BASE), British Library One Search, Lancaster University, Science and Technology Index (Sinta), Garda Rujukan Digital (Garuda), Mendeley dan Dimensions.
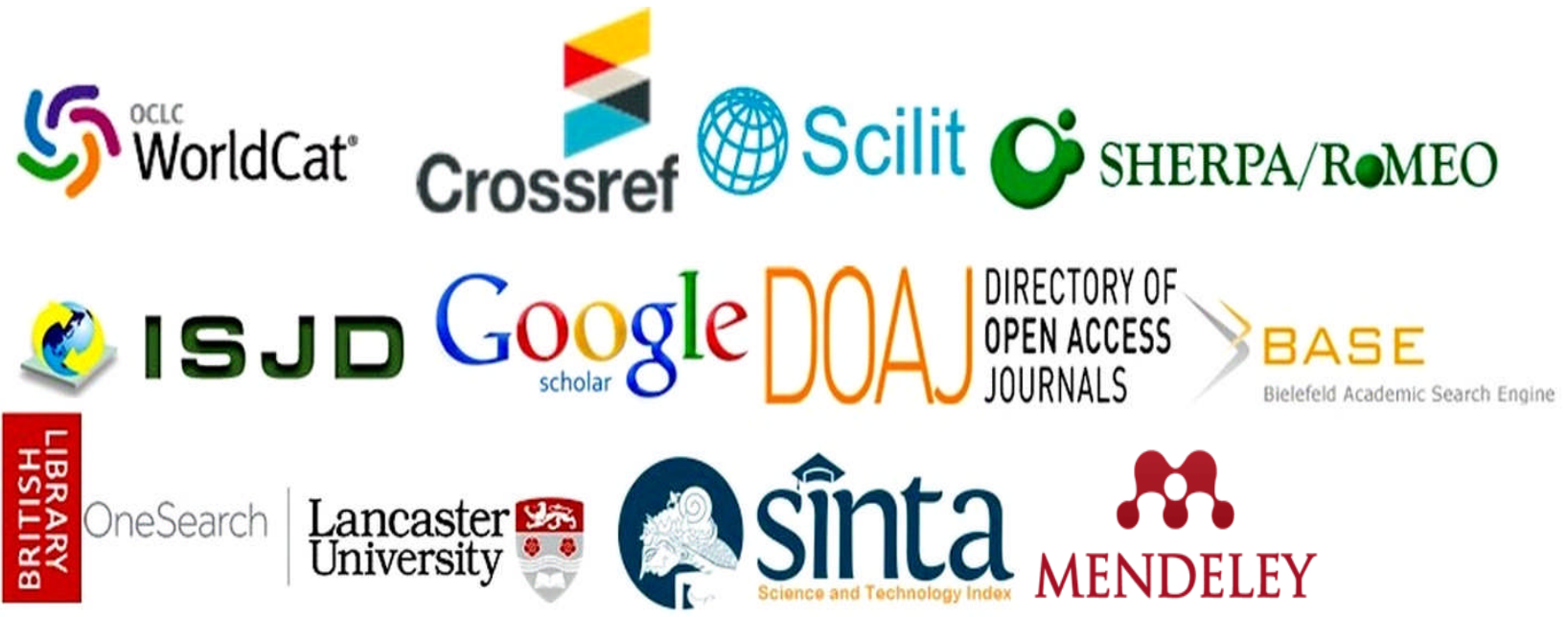

\section{C) GARUDA Dimensions}




\section{BEBESTARI PADA JURNAL PENELITIAN PERIKANAN INDONESIA}

1. Prof. Dr. Ir. Janny Dirk Kusen, MSc, (Biologi Kelautan - Universitas Sam Ratulangi)

2. Prof. Dr. Ir. Sam Wouthuyzen, M. Sc. (Oseanografi Perikanan-Lembaga IImu Pengetahuan Indonesia)

3. Prof. Dr. Ir. Endi Setiadi Kartamihardja, M. Sc. (Pengelolaan Perikanan PUD-Pusat Riset Perikanan)

4. Prof. Dr. Ir. Ari Purbayanto, M. Si. (Metode Penangkapan Ikan-Institut Pertanian Bogor)

5. Prof. Dr. Ir. Indra Jaya (Hidro Akustik Perikanan-Institut Pertanian Bogor)

6. Prof. Dr. Ir. John Haluan, M. Sc. (Sistem Informasi Perikanan-Institut Pertanian Bogor)

7. Prof. Dr. Krismono, M.S. (Sumber Daya dan Lingkungan-Balai Riset Pemulihan Sumberdaya Ikan)

8. Prof. Dr. Ir. M.F. Rahardjo (Iktiologi, Ekologi Ikan, Konservasi Sumber Daya Hayati Perairan-Institut Pertanian Bogor)

9. Prof. Dr. Ir. Setyo Budi Susilo, M.Sc. (Penginderaan Jauh-Institut Pertanian Bogor)

10. Prof. Dr. Ir. Gadis Sri Haryani (Limnologi-Lembaga IImu Penelitian Indonesia)

11. Prof. Dr. Ir. Mennofatria Boer, DEA. (Matematika dan Statistika Terapan-Institut Pertanian Bogor)

12. Dr. Wijopriono (Hidro Akustik Perikanan-Pusat Riset Perikanan)

13. Dr. Ir. Mochammad Riyanto, M.Si. (Teknologi Penangkapan Ikan-Institut Pertanian Bogor)

14. Dr. Purwito Martosubroto, M.Sc. (Dinamika Populasi Ikan-Komisi Nasional Pengkajian Stok Ikan)

15. Ir. Sasanti R. Suharti M.Sc. (Biologi Kelautan-Lembaga IImu Penelitian Indonesia)

16. Dr. Ir. Sudarto, M.Si. (Genetika Populasi-BP2BIH)

17. Dr. Ir. Mohammad Mukhlis Kamal, M. Sc. (Biologi Konservasi Perairan-Institut Pertanian Bogor)

18. Dr. Estu Nugroho (Sumber Daya Genetik Ikan-Pusat Riset Perikanan)

19. Dr. Ir. Zairion, M. Sc. (Pengelolaan Sumber Daya Perikanan-Institut Pertanian Bogor)

20. Dr. Ir. Zainal Arifin, M.Sc. (Kimia Oseanografi-Lembaga Ilmu Penelitian Indonesia)

21. Dr. Ir. Mas Tri Djoko Sunarno, MS. (Nutrisi-Balai Riset Perikanan Budidaya Air Tawar dan Penyuluhan Perikanan)

22. Dr. Ir. Abdul Ghofar, M. Sc. (Pengkajian Stok Sumber Daya Ikan-Universitas Diponogoro)

23. Drs. Suwarso, M.Si. (Sumber Daya Lingkungan-Balai Riset Perikanan Laut)

24. Drs. Bambang Sumiono, M. Si. (Biologi Perikanan-Pusat Riset Perikanan)

25. Ir. Duto Nugroho, M.Si. (Teknologi Penangkapan Ikan-Pusat Riset Perikanan)

26. Ir. Badrudin, M.Sc. (Dinamika Populasi Ikan-Komisi Nasional Pengkajian Stok Ikan)

27. Dr. Ir. Andin Taryoto, M.Si. (Sosiologi Perikanan-Sekolah Tinggi Perikanan)

28. Dr. Priyanto Rahardjo, M.Sc. (Biologi Konservasi-Sekolah Tinggi Perikanan)

29. Dr. Ir. Ario Damar, M.Si. (Ekologi Perairan Pesisir, Phytoplankton Ekologi-Institut Pertanian Bogor)

30. Dr. Fayakun Satria, M.App.Sc. (Sumberdaya dan Lingkungan Perikanan-Balai Riset Perikanan Laut)

31. Dr. Ir. Syahroma Husni Nasution, M.Sc. (Biologi Perikanan-Limnologi, Lembaga Ilmu Penelitian Indonesia)

32. Dra. Sri Turni Hartati, M.Si. (Lingkungan Sumberdaya Perairan-Pusat Riset Perikanan) 
33. Drs. Dharmadi (Sumber Daya Ikan Hiu dan Pari-Pusat Riset Perikanan)

34. Dr. Reny Puspasari, S.Pi, M.Si. (Sumber Daya Perikanan-Pusat Riset Perikanan)

35. Dr. -Ing. Widodo Setiyo Pranowo, M.Si. (Oseanografi-Pusat Penelitian dan Pengembangan Sumber Daya Laut dan Pesisir)

36. Budi Nugraha, S.Pi., M.Si. (Sumber Daya dan Lingkungan-Pusat Riset Perikanan) 


\section{UCAPAN TERIMAKASIH}

Ketua Penyunting Jurnal Penelitian Perikanan Indonesia (JPPI) mengucapkan terima kasih kepada para Bebestari yang telah berpartisipasi dalam menelaah naskah yang diterbitkan di jurnal ilmiah ini, sehingga jurnal ini dapat terbit tepat pada waktunya. Bebestari yang berpartisipasi dalam terbitan Volume 25 Nomor 4 Desember 2019 adalah:

1. Prof. Dr. Ir. Mennofatria Boer, DEA. (Matematika dan Statistika Terapan-Institut Pertanian Bogor)

2. Budi Nugraha, S.Pi., M.Si. (Sumber Daya dan Lingkungan-Pusat Riset Perikanan) 


\section{KATA PENGANTAR}

Jurnal Penelitian Perikanan Indonesia (JPPI) di tahun 2019 memasuki Volume ke-25. Proses penerbitan jurnal ini dibiayai oleh Pusat Riset Perikanan tahun anggaran 2019. Semua naskah yang terbit telah melalui proses evaluasi oleh Dewan Penyunting dan Bebestari serta editing oleh Penyunting Pelaksana.

Penerbitan keempat di Volume 25 Nomor 4 tahun 2019 menampilkan lima artikel hasil penelitian perikanan di perairan Indonesia. Kelima artikel lebih detilnya mengulas tentang: Karakteristik Biologi dan Tingkat Pemanfaatan Udang Windu di Perairan Sebatik, Kalimantan Utara; Respons Rajungan (Portunus pelagicus) Terhadap Warna Cahaya yang Berbeda pada Uji Laboratorium; Distribusi-Kelimpahan dan Hasil Tangkapan Cumi-cumi di Perairan Paparan Sunda Bagian Selatan; Komposisi Hasil Tangkapan dan Daerah Penangkapan Pancing Ulur Tuna di Perairan Sendang Biru; Dinamika Perikanan Payang di Perairan Utara Karawang dan Sekitarnya.

Diharapkan tulisan ini dapat memberikan kontribusi bagi para pengambil kebijakan dan pengelola sumber daya perikanan di Indonesia. Ketua Penyunting mengucapkan terima kasih atas partisipasi aktif para peneliti dari lingkup dan luar Pusat Riset Perikanan.

Ketua Penyunting 


\section{JURNAL PENELITIAN PERIKANAN INDONESIA \\ Volume 25 Nomor 4 Desember 2019}

\section{DAFTAR ISI}

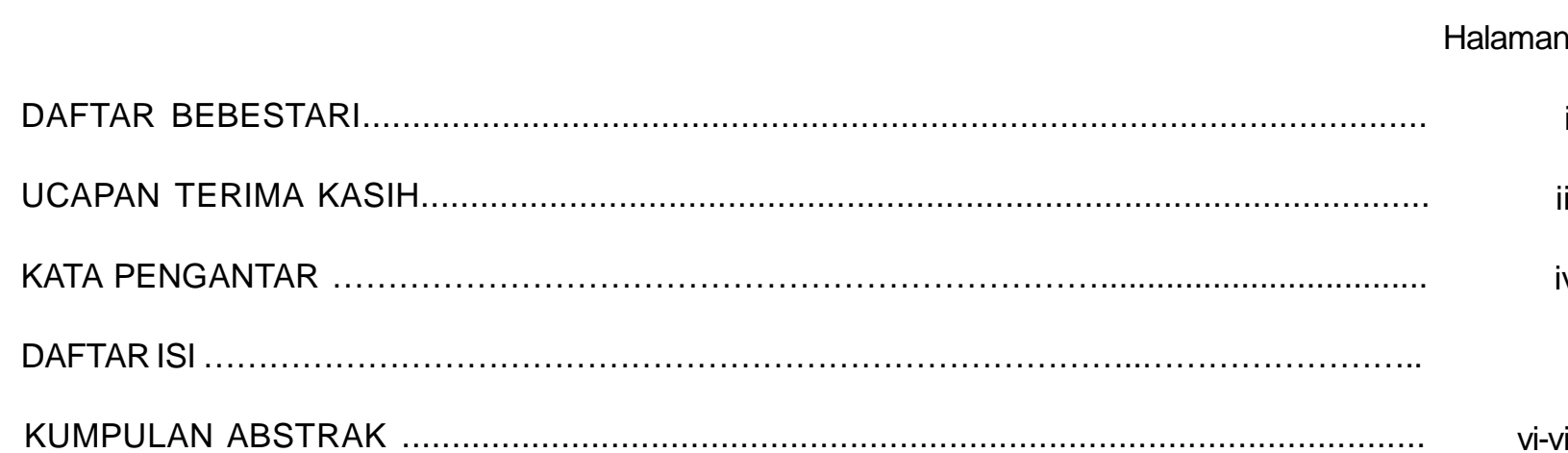

Karakteristik Biologi dan Tingkat Pemanfaatan Udang Windu di Perairan Sebatik, Kalimantan Utara Oleh: Tirtadanu dan Umi Chodrijah

Respons Rajungan (Portunus pelagicus) Terhadap Warna Cahaya yang Berbeda pada Uji Laboratorium

Oleh: Intan Roihatul Jannah Hasly, Roza Yusfiandayani dan Wazir Marwadi

Distribusi-Kelimpahan dan Hasil Tangkapan Cumi-cumi di Perairan Paparan Sunda Bagian Selatan Oleh: Suwarso, Achmad Zamroni dan Moh Fauzi

Komposisi Hasil Tangkapan dan Daerah Penangkapan Pancing Ulur Tuna di Perairan Sendang Biru

Oleh: Maya Agustina, Irwan Jatmiko dan Ririk Kartika Sulistyaningsih

Dinamika Perikanan Payang di Perairan Utara Karawang dan Sekitarnya

Oleh: Mohammad Adha Akbar dan Mufti Petala Patria

SERTIFIKATAKREDITASI. App. 268

PEDOMAN PENULISAN.

App. 269

INDEKS PENULIS

App. 270 


\section{JURNAL PENELITIAN PERIKANAN INDONESIA Vol. 25 No.4 Desember 2019}

\section{KUMPULAN ABSTRAK}

\section{KARAKTERISTIK BIOLOGI DAN TINGKAT PEMANFAATAN UDANG WINDU DI PERAIRAN SEBATIK, KALIMANTAN UTARA}

Tirtadanu

JPPI Desember 2019, Vol 25 No. 4, Hal. 203-214

\section{ABSTRAK}

Keterbatasan data dan informasi hasil tangkapan udang windu (Penaeus monodon Fabricius, 1798) yang tidak terlaporkan di Sebatik menyebabkan sulitnya menduga potensi dan status stok udang windu. Upaya yang dapat dilakukan untuk menduga status stok dan strategi pengelolaan udang yang berkelanjutan di perairan Sebatik adalah melalui kajian karakteristik biologi, perikanan seperti parameter populasi dan rasio potensi pemijahan. Sampel udang diperoleh dari hasil tangkapan nelayan di beberapa daerah pendaratan sekitar Tanjung Aru dan pengumpulan data biometrik udang dilakukan selama bulan April - Desember 2018. Parameter pertumbuhan diperoleh dari pergeseran modus panjang karapas bulanan berdasarkan model pertumbuhan Von Bertalanffy. Tingkat penangkapan diperoleh dari laju eksploitasi $(E)$ dan estimasi rasio pemijahan berbasis data panjang (Length-based SPR). Hasil penelitian menunjukkan rata-rata ukuran udang yang tertangkap jaring tiga lapis adalah $46,90 \pm 0,14$ mmCL pada udang jantan dan $53,40 \pm 0,25 \mathrm{mmCL}$ pada udang betina. Sebagian besar udang yang tertangkap belum melakukan pemijahan $(\mathrm{Lc}=52 \mathrm{mmCL}<\mathrm{Lm}=55$ $\mathrm{mmCL}$ ) dan udang windu memijah sepanjang tahun dengan puncakya diduga terjadi pada bulan Agustus dan November-Desember. Udang betina memiliki ukuran yang lebih besar $\left(\mathrm{L}_{\infty}\right.$ jantan $=66,25 \mathrm{mmCL} ; \mathrm{L}_{\infty}$ betina $=84,50 \mathrm{mmCL}$ ) dan laju pertumbuhan yang lebih cepat $\left(\mathrm{K}\right.$ jantan $=1,27$ tahun $^{-1} ; \mathrm{K}$ betina $=1,39$ tahun $^{-1}$ ) dibandingkan udang jantan. Laju mortalitas alami udang jantan sama dengan udang betina $(M=1,7$ tahun $\left.{ }^{1}\right)$ sedangkan laju mortalitas penangkapan udang jantan lebih tinggi dibandingkan udang betina ( $F$ jantan $=2,13$ tahun $^{-1} ; \mathrm{F}$ betina $=1,70$ tahun $\left.^{-1}\right)$. Status penangkapan udang windu di perairan Sebatik telah jenuh (fully exploited $)(\mathrm{E}=0,50-0,56)$ dan kondisi stoknya tidak berada pada kondisi growth overfishing berdasarkan estimasi rasio potensi pemijahan sebesar $34 \%$. Pengusahaan udang windu di perairan Sebatik dapat terus dilanjutkan dengan menghindari penangkapan yang terpusat di daerah asuhan.

Kata Kunci: Fully exploited; jaring tiga lapis; Penaeus monodon; Sebatik; Status penangkapan

\section{RESPONS RAJUNGAN (Portunus pelagicus) TERHADAP WARNA CAHAYA YANG BERBEDA PADA UJI LABORATORIUM}

Intan Roihatul Jannah Hasly

JPPI Desember 2019, Vol 25 No. 4, Hal. 215-224

\section{ABSTRAK}

Tingkah laku ikan merupakan salah satu pendekatan dasar dalam mengembangkan teknologi penangkapan ikan. Pengetahuan tentang respons tingkah laku menjadi bagian tidak terpisahkan sebagai akibat dari perlakuan yang diberikan. Penelitian ini bertujuan untuk menganalisis respons rajungan terhadap berbagai warna cahaya dilihat dari proporsi rajungan mendekati cahaya, waktu kedatangan rajungan menuju area lampu dan lama rajungan bertahan di area lampu. Respons rajungan diketahui dari pembagian area yang telah dibagi menjadi tiga bagian, yaitu starting area, searching area dan finding area. Analisis statistik deskriptif komparatif digunakan untuk mengetahui adanya perbedaan respons berdasarkan waktu dan jumlah rajungan menuju cahaya. Hasil pengujian menunjukkan bahwa rajungan memberikan respon untuk menghampiri lampu baik secara langsung maupun tidak langsung terhadap cahaya. Warna biru, putih dan hijau memberikan respons cepat bagi rajungan untuk datang ke lampu, sementara rajungan bertahan lama dalam cahaya merah, oranye dan ungu. Hasil penelitian ini dapat diterapkan sebagai pertimbangan untuk pengembangan teknologi alat penangkapan rajungan seperti bubu dan jaring insang dasar.

Kata Kunci: Perbedaan warna; cahaya; tingkah laku; rajungan; laboratorium

\section{DISTRIBUSI-KELIMPAHAN DAN HASIL TANGKAPAN CUMI-CUMIDI PERAIRAN PAPARAN SUNDA BAGIAN SELATAN: \\ Berbasis pada perikanan Jaring Cumi yang mendarat di Muara Angke dan Kejawanan}

Suwarso

JPPI Desember 2019, Vol 25 No. 4, Hal. 225-239

\section{ABSTRAK}

Perikanan cumi-cumi telah berkembang di Laut Jawa dan Laut Cina Selatan, didukung oleh alat tangkap bouke ami dan cast net dengan armada penangkap 
skala menengah. Perikanan berkembang sebagai bentuk diversifikasi usaha penangkapan beralih target species akibat terjadinya pergeseran trophic level yang berkaitan dengan perubahan ekosistem serta indikasi pergantian populasi dari sumberdaya 'multi-species'. Kajian distribusi, kelimpahan dan hasil tangkapan Cumi-cumi (Loliginidae) di perairan Paparan Sunda bagian selatan didasarkan pada data monitoring oleh enumerator tahun 2018 terhadap alat penangkap cumicumi (bouke ami dan cast net), didukung oleh data pendaratan per kapal di TPI Muara Angke (Jakarta) periode 2012-2018 dan TPI Kejawanan (Cirebon) periode 2008-2018. Observasi lapangan ditujukan untuk mendeskripsikan karakteristik armada, alat tangkap dan aspek operasional penangkapan. Hasil menunjukkan daerah penangkapan cumi-cumi di Paparan Sunda bagian selatan tersebar luas di Laut Jawa dan Laut Cina Selatan, tapi lebih terkonsentrasi di perairan selatan Selat Karimata yang ditunjukkan oleh tingginya intensitas penangkapan $(54 \%$ dari total trip penangkapan). Namun demikian, secara umum kelimpahan cumi-cumi (ditunjukkan oleh indek kelimpahan CPUE dalam $\mathrm{Kg} / \mathrm{hari}$ ) hampir seragam sekitar 113-133 kg/hari, sedang indek kelimpahan (CPUE) dalam Kg/trip terlihat berbeda. Perbedaan nyata juga terlihat dari total hasil tangkapan cumi-cumi dari Selat Karimata yang mencapai $55 \%$ dari total pendaratan cumi-cumi dari paparan tersebut. Secara umum sebagai target species cumi-cumi berkontribusi sebanyak 93\% dari total hasil tangkapan pada alat penangkap cumi. Trend kenaikan hasil tangkapan cumi-cumi berlangsung hingga saat ini baik di Muara Angke maupun Kejawanan. Dalam komposisi jenis prosentase cumi-cumi juga menunjukkan semakin tinggi pada hasil tangkapan pukat (cantrang). Hal-hal terkait pengelolaan perikanan cumi sebagai diversifikasi usaha penangkapan dan pengalihan target species juga dibahas.

Kata Kunci: Sumberdaya Cumi-cumi (Loliginidae); bouke ami; cast net; daerah penangkapan; hasil tangkapan; indek kelimpahan; trend hasil tangkapan

\section{KOMPOSISI HASIL TANGKAPAN DAN DAERAH PENANGKAPAN PANCING ULUR TUNA DI PERAIRAN SENDANG BIRU}

\section{Maya Agustina}

JPPI Desember 2019, Vol 25 No. 4, Hal. 241-251

\section{ABSTRAK}

Tuna, cakalang dan tongkol (TCT) merupakan jenis hasil tangkapan ikan yang memiliki nilai ekonomis penting dan masih terdapat peluang untuk dimanfaatkan. Salah satu sentra perikanan tuna, cakalang dan tongkol di kawasan Indonesia Barat yang terbesar adalah di Kabupaten Malang tepatnya di Pelabuhan Perikanan Pantai (PPP) Pondokdadap Sendang Biru. Jenis alat penangkapan ikan yang digunakan oleh nelayan untuk menangkap tuna di perairan ini adalah pancing ulur (handline) yang dioperasikan dengan menggunakan bantuan rumpon. Tujuan penelitian ini adalah untuk mengetahui informasi sebaran daerah penangkapan (teritorial, ZEE dan laut lepas) dan bagaimana dinamika hasil tangkapannya khususnya tuna, cakalang dan tongkol. Pancing ulur mendominasi alat penangkapan ikan yang digunakan di PPP Pondokdadap, Sendang Biru tercatat sebanyak $70,42 \%$, sedangkan pukat cincin sebanyak $9,82 \%$ dan pancing rawai sebanyak $19,76 \%$. Jenis hasil tangkapan pancing ulur terbanyak adalah cakalang dan juwana tuna. Daerah penangkapan nelayan pancing ulur yang berbasis di PPP Pondokdadap, Sendang Biru menyebar pada kawasan perairan dengan batasan antara $8^{\circ}$ $12^{\circ}$ LS dan $108^{\circ}$ - 115 BT atau secara geografis berada di dalam perairan teritorial, ZEE dan di laut lepas. Prosentase hasil tangkapan TCT yang tertangkap pancing ulur berdasarkan wilayah perairan seperti berikut: teritorial sebanyak 0,63\%, ZEE sebanyak 78,68\% dan di luar ZEE (laut lepas) sebanyak 20,69\%.

Kata Kunci: Daerah penangkapan ikan; komposisi hasil tangkapan; pancing ulur; Sendang Biru

\section{DINAMIKA PERIKANAN PAYANG DI PERAIRAN UTARA KARAWANG DAN SEKITARNYA}

\author{
Mohammad Adha Akbar \\ JPPI Desember 2019, Vol 25 No. 4, Hal. 253-267
}

\section{ABSTRAK}

Perikanan skala kecil terutama perikanan payang merupakan salah satu tulang punggung mata pencaharian masyarakat pesisir di perairan Karawang, Jawa Barat. Peran nyata aktivitas perikanan pada keanekaragaman sumberdaya hayati laut adalah memanfaatkan sumberdaya hayati perairan laut di kawasan pesisir dengan kondisi kelimpahan sumberdaya ikan yang cenderung berfluktuasi pada tingkat yang relatif rendah. Penelitian dilakukan melalui survey lapang pada kurun waktu Agustus - Nopember 2018 dengan basis data hasil tangkapan dan upaya penangkapan pada rentang waktu 2016-2018. Beberapa data lingkungan terkait ragam keadaan cuaca yang digambarkan oleh data curah hujan, arah dan kecepatan angin digunakan untuk menggambarkan siklus adaptasi nelayan untuk mempertahankan mata pencariannya. Aktivitas penangkapan menggunakan perahu dengan tonase $<10$ GT dan rerata kekuatan mesin sekitar 20 PK, beroperasi dalam skala harian dengan alat penangkapan ikan utama adalah jaring payang. Perkembangan tahunan indeks kelimpahan sumberdaya ikan dengan alat tangkap payang pada kurun waktu 2004-2008 dan 2015-2018 cenderung menurun. Tahun 2004 nilai indeks kelimpahan sumberdaya ikan sebesar $268 \mathrm{~kg} /$ trip menjadi $199 \mathrm{~kg} /$ trip pada 2008 dan terus menipis menjadi sebesar 115 $\mathrm{kg} /$ trip tahun 2018. Hal ini mengindikasikan usaha perikanan cenderung berada pada kondisi tidak 
berkelanjutan bila tidak dilakukan pengelolaan. Keberlanjutan usaha perikanan masih dapat diharapkan jika dilakukan perubahan terhadap sistem usaha yang lebih bersifat menjadi gabungan individu perahu yang berukuran kecil menjadi usaha kelompok dengan perahu yang berukuran lebih besar diatas 10 GT dengan daerah penangkapan yang lebih jauh.

Kata Kunci: Dinamika perikanan; nelayan kecil; keberlanjutan; paying; Ciparage 